\title{
3. Demogrāfijas jomas regulējums Latvijas un Eiropas Savienības likumdošanā un politikas dokumentos
}

\author{
Silvija Kristapsone, Ivars Indāns
}

Zinoši, prasmīgi un motivēti cilvēki ir svarīgākais Latvijas resurss un valsts turpmākās izaugsmes pamats. Diemžēl zemais dzimstības līmenis un Latvijas darbaspēka emigrācija uz citām ES dalībvalstīm var novest pie aizvien lielāka cilvēku resursu trūkuma, ja netiek îstenota atbilstoša politika. 2004. gada 1. maijā Latvija kḷuva par pilntiesīgu ES dalībvalsti. Pati par sevi iestāšanās ES automātiski nenodrošina visu problēmu, t. sk. demogrāfisko problēmu Latvijā, atrisināšanu, tāpēc nepieciešama gan valdības, gan pilsoniskās sabiedrības aktīva rīcība ES piedāvāto iespēju izmantošanā. Paralēli ES ekonomiskai attīstībai tiek veicināta ES kopējo politiku veidošana vairākās jomās, t. sk. ārpolitikā. Aizvien ciešākas globālas integrācijas apstākḷıs ES dalībvalstis kopīgi meklē risinājumus jautājumos, kas saistīti ar imigrāciju no trešajām valstīm, organizēto noziedzību, terorismu, nabadzību pasaulē vai klimata pārmaiṇām.

\section{Latvijas likumdošanas un politikas dokumenti}

Demogrāfijas un ǵimenes politikas jautājumi (dzimstības palielināšana, iedzīvotāju novecošanas problēmas risināšana u. c.) ir katras nacionālās valsts kompetencē. Galvenais Latvijas uzdevums demogrāfijas jomā ir sasniegt pozitīvu iedzīvotāju pieauguma līmeni. N̦emot vērā ES kopumā negatīvo demogrāfisko situāciju un tās ietekmi uz Eiropas kopējo attīstību, pieaug nepieciešamība šos jautājumus risināt ES līmenī. Latvijas politikas stratēǵija šajā jomā ir panākt, lai ES līdzekḷi tiktu maksimāli izmantoti Latvijas demogrāfisko jautājumu risināšanai (Latvijas Republikas Ārlietu ministrija, 2007).

Latvijas Republikas Ministru kabineta 1997. februāra Deklarācijas 3.21. punkts paredzēja ilglaicīgas valsts programmas izstrādi un īstenošanu demogrāfiskās situācijas atveseḷošanai, un Latvijas Zinātṇu akadēmijas Senāts, 1997. g. 17. jūnija un 15. jūlija sēdē, konstatējot, ka šajā virzienā nav sākts reāls darbs, pieņem lēmumu "Par demogrāfisko krīzi Latvijā un valstiskas rīcības nepieciešamību tās novēršanai”. Šai dokumentā ir paredzēti uzdevumi Latvijas 
Republikas Saeimai, piemēram, apspriest nevēlamo tendenču novēršanas pasākumus un paplašināt likumā "Par sociālo drošību" paredzētos valsts atbalsta veidus gimenēm ar mazgadīgiem bērniem; Latvijas Republikas Ministru kabinetam izstrādāt un sākt îstenot ilglaicīgu valsts programmu demogrāfiskās situācijas atveseḷošanai, aktivizēt Ministru kabineta Demogrāfijas komisijas darbu (Latvijas Zinātṇu akadēmijas Senāts, 1997).

Ģimeniskās vērtības gadsimtiem ir bijušas nozīmīgas. Uz ğimenes atbalstu faktiski arī vērsta valsts atbalsta politika, un tās galvenie virzieni ir šādi: uz bērnu un gimenes atbalstu vērsta politika, atvieglojumi strādājošiem par apgādībā esošiem bērniem, darba un gímenes dzīves saskanıošanas iespējas, citi monetārie un nemonetārie giimenes atbalsta un dzimstības veicināšanas pasākumi (Ābolina, 2016).

Mūsdienās ǵimenes robežas kḷ̂̄st arvien neskaidrākas. Latvijas Satversmē teikts, ka valsts aizsargā un atbalsta laulību - savienību starp vīrieti un sievieti, gimeni, vecāku un bērna tiesības. Civillikuma 60. panta otrā daḷa vēsta, ka laulïbas mērkis ir izveidot gimeni, tātad ğimenes veidošanas pamats ir laulība un nekas cits. Civillikumā saistībā ar demogrāfiskiem procesiem ietvertas gímenes tiesības un mantojuma tiesības (Civillikums, 2015). Līdzās Eiropas Parlamenta un Eiropas Padomes direktīvām gan Saeima, gan Ministru kabinets ir izdevuši vairākus tiesību aktus, kas ietekmē demogrāfijas jomas regulējumu Latvijā (2. pielikums).

2011. gadā tika izveidota Demogrāfisko lietu padome. Tā ir konsultatīva un koordinējoša valsts institūcija, kas radīta, lai veicinātu vienotu valsts demogrāfisko politiku un tās īstenošanu visos valsts pārvaldes līmeņos. Padome izvērtē un koordinē valsts demogrāfiskās politikas īstenošanu, kā arī informē plašsaziņas līdzekḷus par demogrāfiskās politikas jautājumiem.

Lai nodrošinātu "Deklarācijas par M. Kučinska vadītā Ministru kabineta iecerēto darbību" prioritātes "Demogrāfiskās situācijas uzlabošana, ǵimenes dzīves kvalitāte un sociālais nodrošinājums" ìstenošanu, 2016. gadā izveidota ekspertu sadarbības platforma "Demogrāfisko lietu centrs" tautas ataudzes atbalsta pasākumu izstrādei un pilnveidošanai. To vada Saeimas Budžeta un finanšu (nodokḷu) komisijas Demogrāfijas lietu apakškomisijas priekšsēdētājs.

Kopš Latvijas neatkarības atgūšanas ir izstrādāti un dalēji ieviesti dažādi pasākumi tautas ataudzes veicināšanai. Viena no pirmajām 1991. gadā pēc Ministru padomes pasūtījuma tika izstrādāta kompleksā mērḳprogramma "Latvijas iedzīvotāji", kas gan netika apstiprināta līdzekḷu trūkuma dēḷ (Eglīte, 2013). Valsts ǵimenes politikas îstenošanai MK 2002. gada 28. maijā akceptēja koncepciju "Valsts ǵimenes politika", vēlāk to aizstājot ar "G̣imenes valsts politikas pamatnostādnēm 2011.-2017. gadam". Pamatnostādnes ir vidēja termiņa politikas plānošanas dokuments, kur noteikts ǵimenes politikas mērkisis, politikas rezultāti, rezultatīvie rādītāji un darbības virzieni (Labklājības ministrija, 2011). Demogrāfisko procesu intensitāte cieši saistīti ar iedzīvotāju 
veselības stāvokli. "Sabiedrības veselības pamatnostādnes 2014.-2020. gadam" ir vidēja termiņa politikas plānošanas dokuments, kas izstrādāts saskaņā ar "Latvijas Nacionālo attīstības plānu 2014.-2020. gadam", Pasaules Veselības organizācijas Eiropas reg̣iona stratēgeiju "Veselība 2020", kā arī Eiropas Savienības fondu plānošanas perioda prioritātēm (Ministru kabinets, 2014). Tas izstrādāts, lai turpinātu īstenot aizsākto sabiedrības veselības politiku, kā arī aktualizētu jaunus attīstības mērḳus un rīcības virzienus to sasniegšanai, saglabājot, uzlabojot un atjaunojot Latvijas iedzīvotāju veselības stāvokli. Latvijas iedzīvotāju galvenie nāves cēloṇi ir neinfekciju slimības: galvenokārt sirds un asinsvadu slimības, ḷaundabīgie audzēji un ārējie nāves cēloṇi. Neinfekciju slimību attīstību lielā mērā ietekmē faktori, kas saistīti ar dzīvesveidu, - neveselīgs uzturs, nepietiekama fiziskā aktivitāte un kaitīgi ieradumi (smēḳēšana, alkohola un narkotisko vielu lietošana). Efektīvākā neinfekciju slimību profilakse ir smēḳēšanas atmešana, regulāras fiziskas aktivitātes, veselīga uztura izvēle un adekvāta ķermeņa svara uzturēšana. Sabiedrības veselības politikas virsmērḳis ir palielināt Latvijas iedzīvotāju veselīgi nodzīvoto mūža gadu skaitu un novērst priekšlaicīgu nāvi. Tā, piemēram, līdz 2020. gadam paredzēts par 3 gadiem palielināt veselīgi nodzīvoto mūža gadu skaitu, kā arī par $11 \%$ samazināt potenciāli zaudēto mūža gadu rādītāju. To paredzēts ìstenot, veicinot vienlīdzīgas veselības iespējas visiem iedzīvotājiem, mazinot neinfekciju slimību riska faktoru izplatību, uzlabojot grūtnieču un bērnu veselību, mazinot traumatisma un vides risku ietekmi uz sabiedrības veselību, nodrošinot infekcijas slimību profilaksi, kā arī veidojot kvalitatīvu veselības aprūpes pakalpojumu sistēmu un vienlīdzīgu veselības pakalpojumu pieejamību valsts iedzīvotājiem.

Latvijas demogrāfisko situāciju lielā mērā ietekmē negatīvs starptautiskās migrācijas saldo. Kā viens no iespējamiem iedzīvotāju skaita pieauguma avotiem ir remigrācija. Tā 2013. gada 30. jūlijā Ministru kabinetā tika apstiprināts "Reemigrācijas atbalsta pasākumu plāns 2013.-2016. gadam" (Ministru kabinets, 2013). Šì plāna mērḳis ir atbalstīt un palīdzēt tiem ārzemēs dzīvojošajiem Latvijas piederīgajiem un viņu gimenes locekḷiem, kuri apsver iespēju vai ir jau izlēmuši atgriezties un strādāt Latvijā vai vēlas dibināt savu uzṇēmumu vai attīstīt biznesa saiknes ar Latviju. Latvijas Universitātes Diasporas un migrācijas pētījumu centra (LU DMPC), kura mērķis ir padziḷināti pētît diasporu un migrāciju, publicētajā pētījumā "Remigrācijas politikas salīdzinoša analīze" apkopota informācija par remigrācijas un diasporas politiku Latvijā un citās valstīs, sniedzot rekomendācijas turpmākai remigrācijas politikas attīstībai Latvijā. LU DMPC ar Eiropas Sociālā fonda atbalstu 2014.-2015. gadā realizēts projekts "Latvijas emigrantu kopienas: nacionālā identitāte, transnacionālās attiecības un diasporas politika". Aptaujas rezultātā var iepazīties ar vairāk nekā 14 tūkst. diasporas pārstāvju pieredzi, ar dažādām mītnes zemes valsts un pašvaldību institūcijām, diskrimināciju darbavietā un sabiedrības attieksmi, t. i., 
ar šobrīd visprecīzāko pieejamo informāciju par to, kā jaunajā mītnes zemē jūtas tie, kuri izcelıojuši no Latvijas kopš 1991. gada, un kāda Latvijas valsts palīdzība nepieciešama (LU Diasporas, 2016).

Viens no šobrīd spēkā esošiem Latvijas valsts politikas dokumentiem ir "Latvijas ilgtspējīgas attīstības stratēgijja līdz 2030. gadam", kas ir galvenais Latvijas ilgtspējīgas attīstības plānošanas dokuments, ko apstiprinājusi Latvijas Republikas Saeima. Latvijas ilgtspējīgas attīstības stratēóija tika veidota, analizējot un apzinoties pārmaiṇas, kas saistītas ar globāliem procesiem. Vienas no tām ir demogrāfiskās izmaiñas - iedzīvotāju skaita samazināšanās un iedzīvotāju novecošana (VARAM, 2010).

\section{ES pieejas imigrācijas problemātikai un tiesiskais regulējums}

Analizējot ES imigrācijas politiku, var izškirt trīs galvenās pieejas: nacionālo, starpvaldību un pārnacionālo. Visas šĩs pieejas ir izmantotas jau iepriekš, un arī pašlaik ES politikas attīstība svārstās atkarībā no dominējošās pieejas. Eiropas politikas attīstība liecina par visu pieeju klātbūtni imigrācijas jautājumu risināšanā, tomēr kā kopsaucējs dominē starpvaldību pieeja.

Nacionālā pieeja balstās uz emocionāli kulturālo uztveri un nacionālās identitātes sentimentu. Šìs pieejas pamatā ir ideja, ka ES valstis pašas veido nacionālo politiku un valstij nav pienākuma ielaist svešiniekus. Lai gan ES politika kopumā ir ievērojami attīstījusies, arī šì pieeja, neraugoties uz ES integrāciju, ir spēcīga. Nacionālās pieejas piekritēji uzskata, ka, investējot līdzekḷus migrantu izcelsmes zemēs, laika gaitā izdotos mazināt imigrācijas negatīvās sociālpolitiskās sekas. Nacionālā pieeja atspoguḷojas arī ES likumdošanā, kur imigrācijas jomā dalībvalstīm bija lielas iespējas noteikt savus kritērijus, balstoties uz nacionālajām interesēm.

Starpvaldību pieeja balstās uz iespējamiem kompromisiem, par kuriem spēj vienoties dalībvalstu valdības. Šai pieejai raksturīgs pragmatisms un funkcionalitāte. Starpvaldību pieeja paredz, ka ES imigrācijas politika balstās tikai uz to, par ko visas puses konkrētajā brīdī spēj vienoties. ES Hāgas un Stokholmas programmas ir šādas pieejas piemēri, jo politikas virzieni ir plaši un daudzpusīgi (Council, 2005). Starpvaldību pieeja parasti paredz politisko piedāvājumu viduspunktu, bet atsevišķos gadījumos zemāko iespējamo kopsaucēju, par ko visi dalībnieki konkrētajā brīdī spēj vienoties. Galvenā šìs pieejas problēma ir tā, ka problēmas bieži apsteidz politikas pārvaldību. Šāda politika ir reaǵējoša un lēna, un tas mazina tās efektivitāti.

Pašreizējā ES politika kopš 90. gadu beigām lielā mērā balstās uz starpvaldību pieejas principiem. Nākotnē imigrācija ir pastāvīgs Eiropas sabiedrības attīstības elements. Ja imigrantu plūsma uz ES tiek pienācīgi un labi pārvaldīta, dalībvalstis no tās var gūt ieguvumus ekonomikā, kultūrā un citās jomās, kas arī stiprinās ES vietu pasaulē (Council of the European Union, 2005). 
Pārnacionālā pieeja ir ekonomiski racionāla (merkantila) reakcija uz Eiropas pieprasījumu pēc darbaspēka, tā nerēkinās ar valstu iekšpolitisko nostāju un identitātēm. Šì pieeja balstās uz ES makroekonomisko nepieciešamību un starptautisko konkurenci. Pārnacionālā pieeja izriet no ārējās vides un globalizācijas ietekmes uz ES.

\section{ES kompetences un tās politikas uzdevumi}

ES ir kompetenta pieņemt iecelıšanas un uzturēšanās nosacījumus trešo valstu valstspiederīgajiem, kuri legāli ieceḷo un uzturas kādā no dalībvalstīm nodarbinātības, mācību vai ǵimenes atkalapvienošanās nolūkā. ES atbalsta pasākumus, ko dalībvalstis veic, lai sekmētu legāli dzīvojošu trešo valstu valstspiederīgo integrāciju, mazinātu nelegālo imigrāciju, jo īpaši ar efektīvas atpakaļnosūtīšanas politikas pasākumiem. Nelegāls migrants ir persona, kas ES ieceḷojusi bez atbilstīgas vīzas vai aț̣aujas vai kas uzturas valstī pēc vīzas derīguma termiņa beigām. ES ir kompetenta noslēgt nolīgumus ar trešajām valstīm par trešo valstu tādu valstspiederīgo atpakalıunnemšanu vinu izcelsmes vai tranzìta valstī, kuri neatbilst vai vairs neatbilst nosacījumiem, lai ieceḷotu, uzturētos vai pastāvīgi dzīvotu kādā dalībvalstī.

ES mērķis ir izstrādāt līdzsvarotu pieeju un saskaņā ar to risināt legālās migrācijas jautājumus un apkarot nelegālo imigrāciju. Pareiza migrācijas plūsmu pārvaldība nozīmē arī taisnīgu attieksmi pret trešo valstu valstspiederīgajiem, kuri legāli uzturas dalībvalstīs, stingrākus pasākumus nelegālās imigrācijas apkarošanai un ciešāku sadarbību visās jomās ar trešajām valstīm. ES cenšas panākt vienotu legālo imigrantu tiesību un pienākumu līmeni, kas būtu līdzvērtīgs Eiropas pilsoṇu tiesību un pienākumu līmenim. Saskaņā ar Lisabonas līgumu uz imigrācijas politikas īstenošanu attiecas solidaritātes princips un atbildības, tostarp tās finansiālo seku, taisnīga sadalījuma princips dalībvalstu starpā. Kopš 2008. gada ir pieņemtas vairākas svarīgas direktīvas par imigrāciju un patvērumu, un tuvākajā laikā tiks pārskatītas vairākas citas būtiskas direktīvas.

N̦emot vērā problēmas, kas radās, pieņemot vispārēju noteikumu par visu darbaspēka imigrāciju ES, pašreizējā pieeja paredz pieņemt nozaru tiesību aktus, kurus piemēros migrantu kategorijām, lai izveidotu ES līmeña politiku legālās imigrācijas jomā. Ar Direktīvu 2009/50/EK par trešo valstu valstspiederīgo ieceļošanu un uzturēšanos augsti kvalificētas nodarbinātības nolūkos ir ieviesta tā dēvētā ES zilā karte - operatīva procedūra īpašas uzturēšanās un darba aț̣aujas izdošanai, paredzot daudz pievilcīgākus nosacījumus trešo valstu darbaspēkam un tādējādi dalībvalstīs piesaistot augsti kvalificētus darbiniekus (Eiropas Padome, 2009). Ar Eiropas Parlamenta un Padomes direktīvu (2011/98/ES) nosaka vienotu, vienkāršotu procedūru trešo valstu valstspiederīgajiem, kuri iesniedz uzturēšanās un darba aț̣auju pieteikumu kādā dalībvalstī, 
kā arī nosaka vienotu tiesību kopumu, kāds jāgarantē legāliem imigrantiem (Eiropas Parlaments, 2011).

Direktīva 2014/36/ES, ko pieñēma 2014. gada februārī, reglamentē trešo valstu valstspiederīgo ieceḷošanas un uzturēšanās nosacījumus nodarbinātības (kā sezonas darbiniekiem) nolūkā. Migrējošie sezonālā darba n̦ēmēji var likumīgi un uz laiku uzturēties ES ne ilgāk par pieciem līdz deviniiem mēnešiem (atkarībā no dalībvalsts), lai veiktu no gadalaiku maiņas atkarīgu darbību, vienlaikus saglabājot savu pamata dzīvesvietu trešajā valstī. Šajā direktīvā ir arī precizētas migrējošiem darba ņēmējiem pieškirtās tiesības (Eiropas Parlaments, 2014). Visbeidzot, tādu trešo valstu valstspiederīgo statusu, kuri ir ES pastāvīgie iedzīvotāji, joprojām reglamentē Padomes Direktīva 2003/109/EK, kas grozìta 2011. gadā, lai attiecinātu tās darbības jomu uz bēgliem un citiem starptautiskās aizsardzības sañēmējiem (Eiropas Padome, 2003).

Eiropas Komisija 2010. gada aprīlī publicēja "Rokasgrāmatas par integrāciju politikas veidotājiem un praktiķiem" trešo izdevumu un 2011. gada jūlijā pieñēma Eiropas programmu trešo valstu valstspiederīgo integrācijai. Turklāt kopš 2009. gada ir izveidoti divi jauni instrumenti integrācijas jautājumu risināšanai - Eiropas integrācijas forums (to rīko Eiropas Komisija un Eiropas Ekonomikas un sociālo lietu komiteja) un Eiropas integrācijas tīmekḷa vietne (European Commission).

ES ir pieņēmusi divus pamata tiesību aktus cīņai pret nelegālo migrāciju. Atpakaļnosūtī̌sanas direktīvā (2008/115/EK) ir noteikti kopīgi ES standarti un procedūras attiecībā uz tādu trešo valstu valstspiederīgo atpakaḷnosūtǐšanu, kas dalībvalstīs uzturas nelikumīgi (Eiropas Parlaments, 2008). Dalībvalstīm šì direktīva bija jāīsteno līdz 2010. gada 24. decembrim. Galvenie uzdevumi, kuru īstenošanai būtu jāveic turpmāki pasākumi, ir nodrošināt pareizu šĩs direktīvas īstenošanu, veicināt konsekventu un pamattiesībām atbilstošu praksi, uzlabot dalībvalstu savstarpējo sadarbību un palielināt Frontex (Eiropas Aǵentūra operatīvās sadarbības vadībai pie ES dalībvalstu ārējām robežām) nozīmi.

Savukārt Direktīvā 2009/52/EK ir noteiktas sankcijas un pasākumi, kas dalībvalstīm jāpiemēro pret darba devējiem, kuri pārkāpj aizliegumu nodarbināt trešo valstu valstspiederīgos, kas dalībvalstīs uzturas nelikumīgi. Līdztekus ES ved sarunas par atpakaluzņemšanas nolīgumiem un to noslēgšanu ar izcelsmes un tranzīta valstīm, lai nosūtītu atpakal nelegālos migrantus un sadarbotos cīñā pret cilvēku tirdzniecību (Eiropas Parlaments, 2009). Šie nolīgumi ietver abpusējas sadarbības saistības starp ES un tās trešo valstu partneriem. Ir noslēgtas sarunas un spēkā stājušies nolīgumi ar Honkongu, Makao, Šrilanku, Albāniju, Krieviju, Ukrainu, Bosniju un Hercegovinu, bijušo Dienvidslāvijas Maķedonijas Republiku, Melnkalni, Pakistānu, Serbiju, Moldovu, Gruziju, Armēniju, Azerbaidžānu un Kaboverdi.

Vidējā un ilgā termiņā Eiropas Komisija ierosina darboties četros galvenajos virzienos: 1) nelikumīgas migrācijas stimulu samazināšana; 2) robežu 
pārvaldīšana, glābjot dzīvības un garantējot drošību; 3) kopējas politikas realizācija patvēruma jomā; 4) legālas migrācijas politikas pilnveidošana, nosakot jaunas prioritātes integrācijas politikai un optimizējot migrācijas politikas ieguvumus cilvēkiem un izcelsmes valstīm, piemēram, padarot naudas pārskaitījumus lētākus, ātrākus un drošākus.

\section{Kopsavilkums}

Demogrāfijas un gimenes politikas jautājumi (dzimstības palielināšana, iedzīvotāju novecošanas problēmas risināšana u. c.) ir katras nacionālās valsts kompetencē. Latvijas galvenais uzdevums demogrāfijas jomā ir sasniegt pozitīvu iedzìvotāju skaita pieaugumu. Šai ziņā nozīmīgs uzdevums ir panākt, lai ES līdzekḷi tiktu maksimāli izmantoti sociāldemogrāfiskai attīstībai. Migrācijas politikas jautājumu risināšanā pastāv dalīta kompetence starp dalībvalstīm un ES. Eiropas politikas attīstība liecina par dažādām pieejām imigrācijas jautājumu risināšanā, tomēr dominējošā ir starpvaldību pieeja.

\section{Literatūra un avoti}

Āboliṇa, L. (2016) Ģimenes valsts politika - mērki un izaicinäjumi [https://www.bvef.lu.lv/fileadmin/user_upload/lu_portal/projekti/bvef/konferences/konference74/Plenarsede/L. Abolina_Gimenes_politika_prezentacija.pdf (27.01.2017.)].

Civillikums (2015) [http://likumi.lv/doc.php?id=90223 (25.01.2017.)].

Council of the European Union (2005) Council and Commission Action Plan Implementing the Hague Programme on Strengthening Freedom, Security and Justice in the European Union [http://eur-lex.europa.eu/legal-content/RO/ALL/?uri=uriserv\%3Al16002 (02.08.2017.)].

Eglīte, P. (2013) Iedzīvotāju ataudzes veicināšanai domāto pasākumu līdzšinējais iedarbīgums. Grām.: Cilvēka vērtïba un tās skaitliskā izteiksme: apcerējumi par Latvijas iedzìvotājiem, Nr. 15. Rīga: LZA Ekonomikas institūts, 168 lpp.

Eiropas Padome (2003) Padomes Direktiva 2003/109/EK (2003. gada 25. novembris) par to trešo valstu pilsoṇu statusu, kuri ir kādas dalībvalsts pastāvīgie iedzīvotāji [http://eurlex.europa.eu/legal-content/LV/TXT/?uri=CELEX\%3A32003L0109 (02.08.2017.)].

Eiropas Padome (2003a) Padomes Direktiva 2003/86/EK (2003. gada 22. septembris) par tiesībām uz ǵimenes atkalapvienošanos [http://eur-lex.europa.eu/legal-content/LV/ TXT/?uri=CELEX\%3A32003L0086 (02.08.2017.)].

Eiropas Padome (2009) Padomes Direktiva 2009/50/EK (2009. gada 25. maijs) par trešo valstu valstspiederīgo iecelıšanu un uzturēšanos augsti kvalificētas nodarbinātības nolūkos [http://eur-lex.europa.eu/legal-content/LV/TXT/?uri=CELEX\%3A32009L0050 (02.08.2017.)].

Eiropas Parlaments (2008) Eiropas Parlamenta un Padomes Direktiva 2008/115/EK (2008. gada 16. decembris) par kopīgiem standartiem un procedūrām dalībvalstīs attiecībā uz to trešo valstu valstspiederīgo atgriešanu, kas dalïbvalstī uzturas nelikumīgi [http://eurlex.europa.eu/legal-content/LV/TXT/?uri=CELEX\%3A32008L0115 (02.08.2017.)].

Eiropas Parlaments (2009) Eiropas Parlamenta un Padomes Direktiva 2009/52/EK (2009. gada 18. jūnijs), ar ko nosaka minimālos standartus sankcijām un pasākumiem pret darba devējiem, kas nodarbina trešo valstu valstspiederīgos, kuri dalībvalstīs uzturas 
nelikumigi [http://eur-lex.europa.eu/legalcontent/LV/TXT/?uri=CELEX\%3A32009L0052 (02.08.2017.)].

Eiropas Parlaments (2011) Eiropas Parlamenta un Padomes Direktīva 2011/98/ES (2011. gada 13. decembris) par vienotu pieteikšanās procedūru, lai trešo valstu valstspiederīgajiem izsniegtu vienotu uzturēšanās un darba atḷauju dalībvalsts teritorijā, un par vienotu tiesību kopumu trešo valstu darba nēemējiem, kuri kādā dalībvalstī uzturas likumīgi [http://eur-lex.europa.eu/legal-content/LV/ALL/?uri=CELEX\%3A32011L0098 (02.08.2017.)].

Eiropas Parlaments (2014) Eiropas Parlamenta un Padomes Direktīva 2014/36/ES (2014. gada 26. februāris) par trešo valstu valstspiederīgo ieceḷošanas un uzturēšanās nosacỉjumiem nodarbinātības kā sezonas darbiniekiem nolūkā [http://eur-lex.europa.eu/legalcontent/LV/TXT/?uri=CELEX\%3A32014L0036 (02.08.2017.)].

European Commission. European website on integration [http://ec.europa.eu/ewsi/en/ (27.01.2017.)].

Labklājības Ministrija (2011) Ģimenes valsts politikas pamatnostādnes 2011.-2017. gadam [http://www.lm.gov.lv/upload/berns_gimene/lmpamn_200111_gvp.pdf (28.01.2017.)].

Latvijas Republikas Ārlietu ministrija (2007) Latvijas dalība Eiropas Savienībā - pamatprincipi, mērksis, prioritātes un darbība 2007.-2013. [http://www.mfa.gov.lv/arpolitika/ eiropas-savieniba-arpolitika/es-jautajumi-arlietu-ministrijas-kompetence/es-jautajumu-koordinacija-arlietu-ministrija/latvijas-strategija-es/latvijas-daliba-eiropas-savieniba-ndash-pamatprincipi-merkis-prioritates-un-darbiba-2007-2013 (26.01.2017.)].

Latvijas Republikas Satversme (2016) [http://likumi.lv/ta/id/57980-latvijas-republikas-satversme (26.01.2017.)].

Latvijas Universitātes Diasporas un migrācijas pētījumu centrs (2016) Latvijas diasporas pieredze saskarsmē ar valsts institūcijām un darba devējiem ārpus Latvijas [https://www. diaspora.lu.lv/fileadmin/user_upload/lu_portal/projekti/diaspora/petijumi/Diasporas pieredze_ar_institucijam__zinojums_mitnes_zemes_iestades.pdf (10.07.2017.)].

Latvijas Zinātnuu akadēmijas Senāts (1997) (1997. gada 15. jūlijs, Nr. 46/1) "Par demogrāfisko krīzi Latvijā un valstiskas rīcības nepieciešamību tās novēršanai" [http://likumi.lv/ doc.php?id=209670 (25.01.2017.)].

Ministru kabinets (2013) Ministru kabineta rīkojums Nr. 356 (Rīgā 2013. gada 30. jūlijā, prot. Nr. 41, 78. §) "Par Reemigrācijas atbalsta pasākumu plānu 2013.-2016. gadam" [https://likumi.lv/doc.php?id=258715 (10.07.2017.)].

Ministru kabinets (2014) Ministru kabineta rīkojums Nr. 589 (Rīgā 2014. gada 14. oktobrī, prot. Nr. 51, 53.§) "Par Sabiedrības veselības pamatnostādnēm 2014. -2020. gadam" [https://likumi.lv/doc.php?id=269591 (10.07.2017.)].

VARAM (2010) Latvijas ilgtspējīgas attīstības stratēgija [http://www.varam.gov.lv/lat/pol/ ppd/?doc $=13857$ (27.01.2017.)]. 